\title{
REALISING CHILDREN'S RIGHTS IN EARLY CHILDHOOD IN THE CONTEXT OF THEIR SOCIAL PARTICIPATION: THE CASE OF THE CHILD'S RIGHT TO A FAMILY
}

\author{
MAŁGORZATA TURCZYK ${ }^{1}$ \\ ${ }^{1}$ Jagiellonian University, Institute of Pedagogy, Batorego 12, 31-135 Kraków, Poland. ORCID: 0000- \\ 0003-4095-9294 Email: m.turczyk@uj.edu.pl
}

\begin{abstract}
The article discusses the need to make the culture of children's rights fundamental from the earliest years of their lives, given the idea of children's social participation. Creating and practicing a culture in which children's rights are observed is a task that requires not only a thorough knowledge of children's rights among both parents and teachers but also a wider acceptance of these ideas. Equally important is the creation of an environment for sharing the knowledge of these rights and advocating for them, at home and in early education settings. The academic and colloquial discourse on parental practices and institutional childcare often overlooks the significance of recognizing children's share in safeguarding their human rights. Meanwhile, the processes of early normative socialization are of great importance to children's development, their future attitudes towards law in general, and also towards their human rights and the rights of others. Social participation is where the child can experience his or her rights and learn about respecting the rights of others. With this in mind, the question must be asked as to whether children's rights are realized in early childhood in the context of their participation in the socialization process. The author uses the example of the child's right to a family as a lens through which to observe how the idea of the children's participation in securing children's rights may be realized or violated. The article is based on an analysis of the literature, in which legal discourse and teachings on child-rearing and early education are used as the interpretative context.

KEYWORDS: children's rights, children's participation, early education and upbringing, law
\end{abstract}




\section{INTRODUCTION}

A child cannot 'think like an adult', but in a childlike way, he/she can reflect on adults' serious problems; the lack of knowledge and experience imposes another way of thinking. (Korczak 2012: 47)

E arly childhood is a time of continuous change and developmental challenges for the individual and their family. At various stages of development, the child is thrown into experiencing new dimensions of reality, learning about the world and entering the domain of social life. At the same time, parents and carers constantly face changes and uncertainty regarding the child's personal, social, and cultural development within the normative dimension of parental reality. Living in a family where the culture of respecting the rights of every person is formed and shared is an important challenge in contemporary child-rearing processes. Family and parenting are subject to scrutiny by many researchers from the area of social sciences and humanities, including sociology, education, psychology, law or philosophy. For this paper's purposes, we will focus on the normative character of everyday family life as experienced by children in the early years of their life when their human rights are either respected or not. I apply the context of securing the child's right to family life as a unique perspective from which the possible areas of children's participation and normative socialization, so essential to their functioning in later life, are examined.

\section{RESEARCH METHOD AND PROCEDURE}

The main organizing issue is focused on the possible ways in which the child's rights are realized and observed in early childhood in the context of their participation in the socialization process. The paper is structured into three parts:

(1) analysis and interpretation of research material related to the protection of the child's rights in early childhood. The purpose of these theoretical considerations is to present the legal foundations for the implementation of children's rights in the family, as well as point us in the direction of the responsibilities of the state and parents in the process of securing the child's rights,

(2) analysis of the category of 'child participation' and how important it is to protect it in the process of early normative socialization,

(3) and, finally, bringing this idea together with the actual situation related to the safeguarding of the child's human rights in the family and the possible dimensions of realizing the idea of child's participation in this sphere.

The purpose of the article is to indicate the importance of the realization of children's rights during early normative socialization for the whole process of participation, so as to develop children's knowledge, understanding and acceptance of their rights. The practical purpose is to inspire the creation of educational practices based on realizing the child's rights and participation.

The method of content and normative analysis was chosen in Polish and interna- 
tional legislation to protect the child's right to being brought up in a family, highlighting several specific problem areas. The author's interpretation of the material gathered was carried out based on a literature review related to child-rearing, early education, and the related legal literature. It references the legal discourse and the use of pedagogical instruments that constitute the background for the analyses. Thanks to applying the content analysis technique, the interpretive context of the research has been enriched with the author's professional experience of working for the Committee on the Rights of the Child and the analysis of documents and reports related to the protection of children's rights in Poland. The social experience of the COVID-19 pandemic further highlights the issue, as it interferes with the realization of the children's right to contact with their loved ones in the case of their separation.

\section{THE RIGHT OF THE CHILD TO A FAMILY IN THE LIGHT OF THE ANALYSIS OF NATIONAL LEGISLATION AND INTERNATIONAL LEGAL STANDARDS}

The child's right to a family upbringing, broadly understood, and parents' corresponding rights and duties to make a personal effort to safeguard the child's best interests (Kusztal 2018) are part of a human being's private and family life, protected both by international law and national legal regulations.

The protection of family rights, including the child's right to be brought up in the family, is also one of the Republic of Poland's basic constitutional principles. Children and parents' rights constitute principles protected by the Constitution of the Republic of Poland of 1997 (Articles 18, 72, paragraph 2, 48). Their particularization is contained in acts of parliament, such as the Act of February 25, 1964, the Family and Guardianship Code (Journal of Laws 1964 No 9, item 59), the Act of October 26, 1982, on proceedings in cases of minors (Dz.U. 1982 No 35, pos. 228). The Act of June 9, 2011, on family support and the foster care system (Dz.U. 2011 No 149, pos. 887) and the Act of July 29, 2005, on counteracting violence in the family (Dz.U. 2005, No 180, pos. 1493).

The European Convention on Human Rights and Fundamental Freedoms states in Article 8 that:

“(1) Everyone has the right to respect for his private and family life, his apartment and his correspondence.

(2) Public authorities may not interfere in the exercise of this right unless it is lawful and necessary in a democratic society in the interests of national security, public safety or the economic well-being of the country to prevent disorder or crime, to protect health or morals, or to protect the rights and freedoms of others." 1

The legislator has used the general term "everyone" means that both parents and

\footnotetext{
${ }^{1}$ Art. 8 of the European Convention for the Protection of Human Rights and Fundamental Freedoms, JoL 1993, No.61, item 284. The Convention was adopted by the 12 member states of the Council of Europe in 1950 and entered into force in 1953. Forty-seven states are parties to the Convention (June 2015) to say all member states of the Council of Europe. Poland ratified the Convention in 1993.
} 
children have the right to have their family and private lives respected. In the case of this law, any interference from the public authorities is inadmissible - except for the cases specified in the act, related to the protection of rights and freedoms of others or preventing crime. The European Tribunal of Human Rights (ETHR), founded in 1959, is a guarantor of the convention. It extends the right to submit an official complaint to individuals and states that are party to the Convention (international complaint) to pursue the rights and freedoms guaranteed by the Convention. The Tribunal is obliged to investigate each submitted case to determine whether the interference of an individual or the state with family life was necessary, compliant with the binding laws, and whether it secures individuals' rights. The extensive jurisdiction of the European Tribunal of Human Rights includes many situations in which the right of the child to life in the family ${ }^{2}$ may be considered to have been violated. Importantly, however, the European Tribunal takes the view that the "relationship between the parents and the child is of such considerable value that all necessary steps must be taken to provide help to the child without depriving him or her of the family environment. Besides, both parental rights and the interest of the child linked to the family are elements of private and family life, which public authorities should consider before making any decisions regarding the family" (Smyczyński 1999:159). Therefore, any decisions about possible interference in the area of the child's rights should be thoroughly investigated in terms of the child's best interest under the circumstances and aim to secure the child's right in the family environment.

Also, other international legal documents point us in the direction of the special protection measures for the family and the child. The doctrinal achievement of the human rights movement and growing interest of the international community in a particular need to protect the child's rights as part of the protection of family life led to creating the document which directly refers to the safeguarding of the rights of children. The Convention on the Rights of the Child of November 20, 1989 (Dz.U. 1991 No. 120, item 526). This comprehensively tackles the issues related to protecting children's rights and how they can be promoted. It also refers to the rights realized in the family context discussed in this paper. The Preamble of the Convention sets out the idea of the protection of the child's rights in the family by providing that "The family, as the fundamental group of society and the natural environment for the growth and well-being of all its members and particularly children, should be afforded the necessary protection and assistance so that it can fully assume its responsibilities within the community. It should be recognized that the child, for the full and harmonious development of his or her personality, should grow up in a family environment, in an atmosphere of happiness, love and understanding." The Convention's regulations that follow make the general provisions of the preamble even more specific, which allows for an interpretation of the existence of the child's right to a family (Smyczyński 1999:151). This category contains such normative areas of competence as:

(a) Respect for the responsibilities, rights and duties of parents/guardians "to provide, in a manner consistent with the evolving capacities of the child, appro-

\footnotetext{
${ }^{2}$ https://www.echr.coe.int/Documents/FS_Childrens_ENG.pdf, accessed on September 152020.
} 
priate direction and guidance in the exercise by the child of the rights recognized in the present Convention" (Article 5 of the Convention on the Rights of the Child).

(b) Ensure that a child shall not be separated from his or her parents against their will, except when competent authorities subject to judicial review so determine, following applicable law and procedures (Art 9, section 1). Significantly, however, Article 3 of the article provides that "States Parties shall respect the right of the child who is separated from one or both parents to maintain personal relations and direct contact with both parents regularly, except if it is contrary to the child's best interests." The legislator also ensures that the child as well as the parent have the right to information on each other's place of residence if the separation is due to an action initiated by the state, such as detention, imprisonment, exile, deportation or death (including death arising from any cause while the person is in the custody of the state) (Stadniczeńko 2015:86)

The Child's formulated Right to be Raised in the family is a set of rights that derive directly from Articles 5 and 9 of the Convention on the Rights of the Child. The normative content of Article 18 is relevant to this area, indicating specific obligations/ tasks on the part of the state to secure the rights of the child in the family.

Article 18

"1. States Parties shall use their best efforts to ensure recognition of the principle that both parents have typical responsibilities for the upbringing and development of the child. As the case may be, parents, or, as the case may be, legal guardians, have the primary responsibility for the upbringing and development of the child. The best interests of the child will be their basic concern.

2. For the purpose of guaranteeing and promoting the rights set forth in the present Convention, States Parties shall render appropriate assistance to parents and legal guardians in the performance of their child-rearing responsibilities and shall ensure the development of institutions, facilities and services for the care of children.

3. States Parties shall take all appropriate measures to ensure that children of working parents have the right to benefit from childcare services and facilities for which they are eligible.

The obligation on the part of the State Party to take special care of supporting the family in fulfilling its child-rearing functions and securing the child's rights is an important challenge for the state's family assistance system. The combined fifth and sixth reports on the implementation of the Convention on the Rights of the Child in Poland (Report 2018) indicate that these objectives are pursued by the Family 500+ program adopted in 2016. The program's primary goal should be to invest in human capital - through money transfers, children can be provided with better education, food, and access to medical treatment. The relationship between securing children's 
rights in early childhood and investing in young children's education seems to have been evident for years. Good education and securing the child's fundamental rights in education pays off, contributes to building social capital, and equalizes each child's educational opportunities. Unfortunately, in the program's promotional materials, more emphasis is placed on reducing the financial burden associated with child-rearing, supporting families in their childbearing plans and encouraging decisions about having a larger family than about building social capital by securing fundamental rights. The report also points to the "Good Start" Program, introduced in 2018, which assumes a once-a-year benefit of PLN300 for each child in education, which helps families manage the expenses related to the beginning of the school year.

The state's tasks in supporting parents who work, and developing institutions for the care of young children, are supported by the Act of February 4, 2011, on the care of children up to 3 years old (Journal of Laws 2011, No. 45, item 235) and the program for the development of childcare institutions for children up to 3 years old "Toddler +" (Maluch +). Subsequently, in the years 2011-2018 the number of places in crèches, children's clubs and also the number of day carers increased from 32, 000 to 145, 900, and the percentage of children up to 3 years old in day care rose from $4.4 \%$ to $19.8 \%$ (Report 2018). Additionally, as of 2013, parents may take paid annual leave due to a child's birth. In 2016, a parental benefit was also introduced for PLN 1,000, paid to parents who are not entitled to maternity benefit. The report also indicates the ban on trading on Sundays, introduced in 2018, to enable families to spend quality time together.

The questions formulated by the Committee on the Rights of the Child after the analysis of the Polish Report indicate the need for the Polish government to specify the actions taken to create a system for the identification of budget allocations and expenditure on children by individual ministries in order to ensure the objective assessment of the adequacy and effectiveness of public spending in this area. The lack of specific mechanisms for ensuring a transparent and participatory budgeting process, particularly with children's participation (UN 2018), was also pointed out.

Securing the realization of children's rights early in life undoubtedly requires state institutions' support and increased spending on social and pedagogical projects of preventive and compensatory nature (Segment 2010:135). Safeguarding the needs of the child at this early stage of development and creating favorable conditions for proper child-rearing and the meeting of the educational needs of children, as part of the concern for the child but also for the future of society as a whole, must be supported by the state following Article 18 of the Convention on the Rights of the Child. Such support should be comprehensive and carried out in a considerate and thoughtful manner, involving the allocation of funds and, perhaps above all, the participation of specialists and other persons supporting families and children in the difficult process of education respect of human rights. 


\section{PARTICIPATION OF CHILDREN IN THE REALISATION OF THEIR HUMAN RIGHTS IN EARLY CHILDHOOD}

When studying children, we should bear in mind that we have before us a permanent class, more significant than the adult population... As members of society, we find they have received almost no attention. They are... not recognised as belonging to society. (Gilman 2009: 43)

Even though the study of the discourse on child and youth participation has a long tradition in sociological, pedagogical, and historical research, the participatory discourse's evolution is still an exceedingly dynamic process (cf. Jarosz 2020; Lansdowne 2010; Wyness 2012; Liebel 2017). It is useful for these considerations to explain how child participation and its role in bringing up a child to respect human rights are understood. Thinking of small children and childhood, adults and educators often believe that they know best what is good or bad for the child. The child's voice in matters concerning him or her is often not heard because the culture of respect for the child's rights in early childhood is not being created or observed. Social impulses to listen to the child's voice have, over the years, been motivated by the theories and practices of pedagogical and social education and care for children. Here we might mention the pedagogical theory and practice of Janusz Korczak, for whom a child is a human like any other: "A child - already a resident, citizen, man... not will he be, but already is" (Korczak 1928), and he continues by saying "One of the worst blunders is to think that pedagogy is the science of the child; no! It is the science of man ... There are no children, there are people, but with a different conceptual scale, different range of experience, different urges, different emotional reactions" (Korczak 1967: 248). For Korczak "The child is a rational being. He knows full well what his needs, difficulties and obstacles in life are. Needed is not a despotic order, imposed discipline and distrustful control but tactful understanding, faith in experience, cooperation and coexistence" (Korczak 1992: 176).

The development of movements calling for social equality and the definition of children as a minority group which is discriminated against, manifestos concerning children (Concerning Children 1990), and the emergence of manifestos and declarations protecting children from exploitation and violence (Geneva Declaration 1924, Declaration of the Rights of the Child 1959) paved the way for the normalization of the pedagogical idea of the protection of children's rights. This way of "creating order in the world of children" that Korczak spoke for as early as 1933 when he wrote, "what a contemporary tragedy life is and what a disgrace to this generation, which passes on to children a disordered world" (Korczak; Liebel \& Markowska-Monista 2017: 28) took the form of an international agreement, ratified by almost all the countries of the world.

The sense of the idea of child participation was defined in more detail in the normative language of the 1989 Convention on the Rights of the Child, as the following rights:

(a) the right to formulate and express one's views freely, and on the part of the 
adults to give these views due weight in accordance with the age and maturity of the child:

(b) the right to freedom of expression.

(c) the right of access to appropriate information.

(d) the right to freedom of thought, conscience and religion.

(e) the right to freedom of association and freedom of peaceful assembly.

(f) the right to have one's privacy fully respected.

(g) the right of access to information, including the information on the child's rights.

Researchers of child participation emphasize the crucial role of the normative proclamation of rights in children's case. The Convention on the Rights of the Child, confirming in the language of legal norms the right of each child to self-determination and to be listened to and heard, at the same time defined the child's status as an equal citizen, a social partner capable of expressing his or her position and taking co-responsibility (Wyness 2012; Liebel \& Markowska-Monistra 2014; Smolinska-Theiss 2012). In this perspective, the child's rights are no longer merely theoretical declarations based on lofty ideals and the good or bad will of adults towards the child but they become principles of law aimed at protecting children. Legislation alone is not enough to create a living environment in which the child experiences true protection and the possibility of realizing their human rights. The real participation of children is essential for the development of their knowledge and acceptance of their rights.

\section{DIMENSIONS OF PARTICIPATION IN THE REALISATION OF THE CHILD'S RIGHTS IN EARLY CHILDHOOD}

The child's right to be listened to and heard is externalized and objectified through the act of speech. In this way, the child realizes his or her essential ability as a human being, creating their world and accumulating knowledge (Rancière 1991). Exchanging words with others builds new dimensions in the relationship between the child and his or her immediate environment, which is based on respect for the child and respect for the child's human rights. Arguing in this vein, McLamon's approach to the child's rights (2008) proposes that every child, regardless of age, can convey to adults what is important to them. It is up to the adults to listen and understand what the child has to say and respond appropriately. It is only an attentive adult attitude towards the child that enables the child to find a complete expression for his or her voice and influence the surrounding reality.

Swedish researchers who studied the culture of children's rights at school have identified four elements necessary for its existence in the educational environment (Brantefors, Tellgren \& Thelander 2019). Based on their theory, I propose to further 
specify the four dimensions of childhood participation in the period of early childhood, both in the family and early childhood care institutions such as crèches and nurseries. Still, the author proposes that if we were to speak of the full protection of the rights of the child in early childhood, our approach to the child, the issues relating to child-rearing and educational environments should be rooted in the following aspects and dimensions:

(1) Participation - a dimension of the child's full involvement in the life of the family or institution.

(2) Empowerment - i.e., creating conditions for children to get involved in the matters and events relevant to them.

(3) Awareness of rights - this refers to introducing the child into the world of law in general and accompanying him/her in the processes of his/her legal socialization. This attribute is realized by being attentive to the child's relationships in his or her daily life and acquisition of experiences in the world, including those of human rights.

(4) Respect for rights - this dimension permeates the other three and becomes the point of reference for them. This is the aspect that children in early childhood feel and model more than acquiring the knowledge of.

The culture of children's rights formed from early childhood arises from treating children's and human rights as a category not only declared in pedagogical practices but lived through as a value in itself. The child's rights must not be treated as a separate, theoretical part of the child-rearing and educational reality. Parents refer only to difficult situations or in confrontation with state authorities. They should constitute an inherent part of the child's upbringing and educational environment and must be reflected in all children's activities and areas and the family's life. The significance of the rights of the child in early childhood becomes real in everyday educational practice, but also through relationships and family and group norms; through showing everyday interest in the child, taking the trouble to hear and understand the child's voice, respect their opinions, create space for making decisions together and creating a shared reality along with the child. This is when the child's rights become a natural vehicle for their development. Simultaneously, respect for human rights is experienced as a norm of interpersonal relations as an unquestionable principle. This is when child participation becomes factual as the principle of cooperation in the child-rearing and educational space. In this way, the conditions for engaging children in matters and events important to them are created, which helps build an awareness of their rights and others' rights. This in itself creates natural cognitive constructs in the child's mind, as he or she experiences the safeguarding of his or her rights and learns to respect those of others. The processes of normative socialization are then carried out as they should be. The child enters the heteronymous world of norms and learns about the law. At the same time, the process of growing up in respect of human rights is fully initiated, which can be presented with the following diagram: 


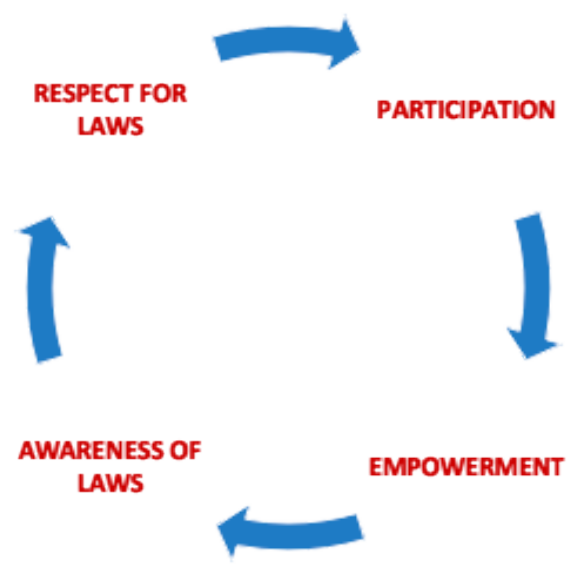

Illustration 1. Dimensions of child participation in the realization of human rights in early childhood.

\section{CONCLUSIONS}

The full realization of children's rights in early childhood is crucial, not only as seen from the perspective of the entire child-rearing process, but mainly from the point of view socialization and the creation of social capital, in terms of having trust in the rule of law. The research undertaken by sociologists of law with regards to knowledge of law and adult attitudes towards law demonstrates that the knowledge of and ideas about law, along with the attitudes towards it that are formed in early childhood (in the phase of primary socialization), constitute a fixed basis for the person's whole future system of ideas, beliefs and approaches to law. These are essential foundations even if the system itself becomes reorganized during the human experience (Borucka-Arctowa and Kourilsky 1993). Moreover, the way children experience the legal system and understand it during childhood can play a significant role, affecting their later tendency towards antisocial behaviors (Niemi 1973). Early childhood is, therefore, a crucial stage in forming the child's attitudes towards law and for the process of internalizing social values; the sources of these values and mindsets can be found in these childhood experiences (Cohn, White. 1990). The role of legal and other social norms in social exclusion or inclusion is clear and well discussed in the literature on the subject (Durhheim 1990; Chambliss 1973; Świd 1960; Buss 2011).

Therefore, the respect for and realization of children's rights from the earliest years of their lives, creating space for their social participation by involving them in the processes of co-determination and co-responsibility for all matters concerning them, can be the best prevention of deviant behaviours, offences or crimes. Some researchers have stressed the role of an appropriately secured process of legal socialization of children even more emphatically, presenting it as a guarantee of compliance with the law in adulthood (Buss 2011). By adopting the sociology of law, we can understand and explain how adults and adolescents respond to law and the reasons behind such 
responses.

It is worth bearing in mind that children "learn the law through experience; they learn equality through the ways they are treated in the classroom, not from the dogmatic analysis of laws. The same applies to the right to express opinions, respecting the dignity of others. We teach children rights leading by example rather than by dictating norms and writing out standards on boards, which does not mean that the latter has no value in itself” (Utrat-Milecki 2012: 140).

\section{ORIGINALITY/VALUE}

The research presented here may help understand the importance of early normative socialization of the child to safeguard the child's rights and human rights. The results of the conducted analyses show how important it is to create a proper educational environment from the first years of the child's life in the sphere of securing their rights, taking into account the principles of participation and education regarding the rights of others. The raising and early education of a child rooted in participation and empowerment principles lead to the experience and awareness of rights and help develop overall respect for legal norms. The experience of one's legal subjectivity and the agency in realizing other people's rights may become the factors protecting children from getting involved in behaviours incompatible with the binding legal norms later in life. The article's theoretical and practical aspects may become an inspiration and a source of information required to create appropriate support mechanisms for families with young children and develop recommendations for local authorities and educational institutions.

FUNDING: This research received no external funding.

CONFLICT OF INTEREST: The author declares no conflict of interest.

\section{REFERENCES}

Borucka-Arctowa, Maria \& Chantall Kourilsky, eds. 1993. Socjalizacja prawna. Warszawa: Agencja Scholar.

Brantefors, Lotta, Britt Tellgren \& Nina Thelander. 2019. "Human Rights Education as Democratic Education. The Teaching Traditions of Children's Human Rights in Swedish Early Childhood Education and School." The International Journal of Children's Rights 27(4): 694-718. Doi: 10.1163/15718182-02704007.

Buss, Emily. 2011."Failing Juvenile Courts, and What Lawyers and Judges Can Do About It.” Northwestern Journal of Law \& Social Policy 6/2011.

Cohn, Ellen S. \& Susan O. White. 1990. Legal Socialisation: A study of Norms and Rules. New York. 
Gilman, Charlotte P. 2009. Concerning Children. Walnut Creek, CA: AltaMira Press (first published 1900).

Handbook on European law relating to the rights of the child. 2017. Luxembourg: Publications Office of the European Union.

Korczak, Janusz. 1967. Selected Works. Warszawa: Published for the national science foun- dation, Washington DC.

Korczak, Janusz. 1928. The Child's Right to Respect. Warszawa: Drukarnia Narodowa.

Korczak, Janusz. 1967. Selected works of Janusz Korczak. National Science Foundation.

Korczak, Janusz. 1992. When I Am Little Again; And the Child's Right to Respect. University Press of America.

Korczak, Janusz. 2012. Jak kochać dziecko. Warszawa: Wydawnictwo Rzecznik Praw Dziecka.

Liebel, Manfred \& Urszula Markowska-Monista. 2014. "Adultism and age-based discrimination against children.” Pp. 119-143 in Children and non-discrimination: Interdisciplinary textbook, edited by D. Kutsar \& H. Warming. Tartu: University of Estonia.

Rancière, Jacques. 1991. The Ignorant Schoolmaster. Five Lessons in Intellectual Emancipation. Trans. K. Ross. Stanford: Stanford University Press.

Segiet, Katarzyna. 2010. ”Dziecko i dzieciństwo jako wartość a współczesność.” Chowanna 1:129-137.

Smolinska-Theiss, Barbara. 2012. The Year of Janusz Korczak 2012. There are no Children, there are people. Warszawa: Wydawnictwo Rzecznika Praw Dziecka.

Utrat-Milecki, Jarosław. 2002. „Wokół istoty praw dziecka.” in Być dzieckiem i przetrwać, edited by B. Głowacka \& L. Pytka. Warszawa: Wyd. Krajowy Komitet Wychowania Resocjalizującego.

Wyness, Michael. 2012. Childhood and Society. $2^{\text {nd }}$ edition. Basingstoke: Palgrave Macmillan.

\section{LEGAL SOURCES}

Europejskiej konwencji o ochronie praw człowieka i podstawowych wolności, JoL 61 (1993): 284.

Right of access to a court (Article 6 of the Convention). Retrieved September 15, 2020 (https://www.echr.coe.int/Documents/FS_Childrens_ENG.pdf).

Unicef. 1989. “Convention on the Rights of the Child.” Retrieved March 31, 2020 (https://www.ohchr.org/en/professionalinterest/pages/crc.aspx ).

United Nations, List of issues prior to submission of the combined fifth and sixth periodic reports of Poland, CRC/C/POL/QPR/5-6, November 21, 2018, Retrieved March 31, 2020 (https://digitallibrary.un.org/record/3795912?ln=ar). 


\section{BIOGRAPHICAL NOTE}

Małgorzata Turczyk is a researcher and academic teacher. Her research interests are on the border between law and pedagogy and focus on issues of children's rights, broadly understood, and normative socialization and university didactics. She is a author of many works devoted to issues relating to the normative context of pedagogical reality and the process of preparing teachers and educators to undertake education for children's rights and human rights, and to support the development of normative competences. She study the issues of children's rights in the event of their parents' divorce. She also a consultant and therapist with PROFICIO Pedagogical Counseling, which operates at the Institute of Pedagogy of the Jagiellonian University. She is an author and editor of monographs, papers in journals and joint publications, a director of research projects, a certified academic tutor.

OPEN ACCESS: This article is distributed under the terms of the Creative Commons Attribution Non-commercial License (CC BY-NC 4.0) which permits any non-commercial use, and reproduction in any medium, provided the original author(s) and source are credited.

ARTICLE HISTORY: Received 2020-10-01 / Accepted 2021-04-10 
